\title{
(C) OPEN ACCESS \\ Demonstration of entry tear and disrupted intima in asymptomatic chronic thrombosed type B dissection with non-obstructive angioscopy
}

\author{
Satoru Takahashi, Sei Komatsu, Mitsuhiko Takewa, Kazuhisa Kodama
}

Cardiovascular Center, Osaka Gyoumeikan Hospital, Osaka, Japan

\section{Correspondence to Dr Sei Komatsu, \\ plaquemap@yahoo.co.jp}

Accepted 11 April 2018

\section{DESCRIPTION}

A 49-year-old man was referred to our hospital for atypical chest pain, without severe abdominal or back pain. He had a history of smoking and dyslipidaemia. His ECG showed no ST-T elevation. Coronary CT angiography (CTA) suggested moderate left anterior descending artery stenosis. CTA screening for aortic atherosclerosis showed significant calcification (figure 1A) and a crescent-shaped, mural low-density area in the infrarenal abdominal aorta (figure 1B,C). This was thought to be an intramural haematoma or a thrombosed false lumen. Calcified spots were deposited at the boundaries between the lumen and the low-density area (figure 1B,C). An intramural haematoma or a thrombosed type B dissection can be asymptomatic. Invasive coronary angiography showed no significant stenosis.

Non-obstructive angioscopy (NOA) with a left brachial approach was performed to evaluate the aortic atherosclerosis. ${ }^{1}$ Aortic plaques were observed from the right common iliac artery to the aortic arch. NOA initially detected the clear boundary of the dissection. The intima of one side was reddish compared with that of the normal side. Bleeding was then detected from an approximately $1 \mathrm{~mm}$ entry tear close to the boundary (figure $2 \mathrm{~A}$, video 1 ), and a mobile white thrombus or flap was detected (figure 2B, video2). The salmon pink-coloured intima with its rough surface was consistently observed (figure 2C). With detection of the

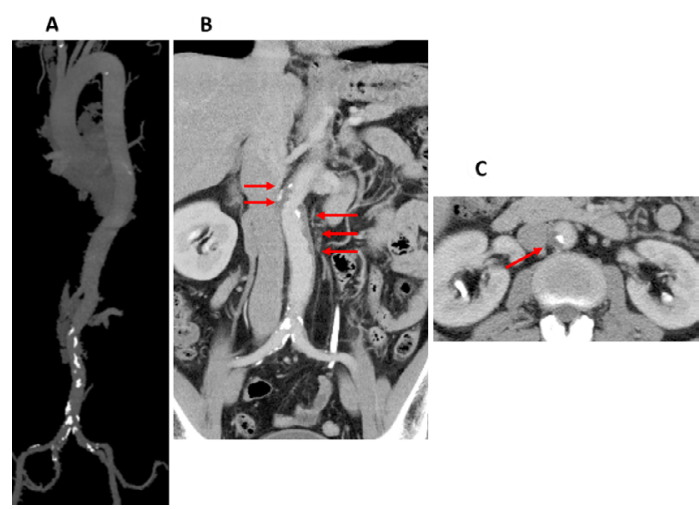

Figure $1 \mathrm{CT}$ angiography images of the aorta. (A) Maximum intensity projection. Calcification deposited in the infrarenal abdominal aorta; however, a few calcifications were found in other sections. (B) Coronal view of the abdominal aorta. Red arrows show the false lumen. (C) Axial image at the T12-L1 level. Red arrows show the false lumen with calcification.
A
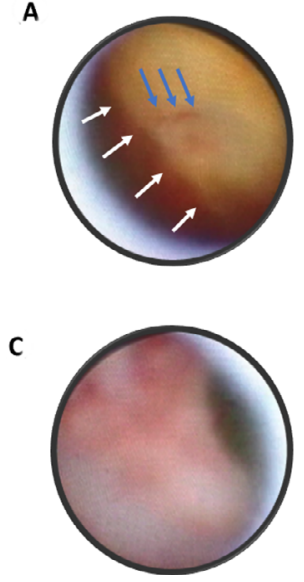

Figure 2 Angioscopic images of aortic ruptured plaques on the surface of the type $B$ thrombosed dissection. (A) Clear boundary (white arrows) of the bright yellow area with smooth surface and red area with irregular surface and bleeding from the entry (blue arrows). (B) Mobile white thrombus or flap (black arrow). (C) Salmon pinkcoloured intima.

entry tear, asymptomatic thrombosed type B dissection was diagnosed.

Blood eosinophil levels on the following day and 30 days later were $0 / \mu \mathrm{L}$ and $63 / \mu \mathrm{L}$, respectively, with a baseline level of $83 / \mu \mathrm{L}$. Serum creatinine levels on the following day and 30 days later were $0.82 \mathrm{mg} / \mathrm{dL}$ and $0.79 \mathrm{mg} / \mathrm{dL}$, respectively, with a baseline level of $0.86 \mathrm{mg} / \mathrm{dL}$. C reactive protein levels on the following day and 30 days

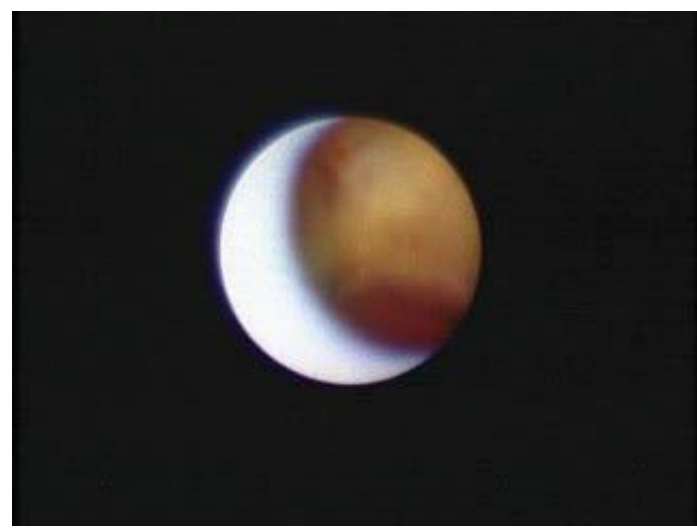

Video 1 Angioscopic video of the boundary of the aortic dissection and normal aortic wall and bleeding from the entry. 


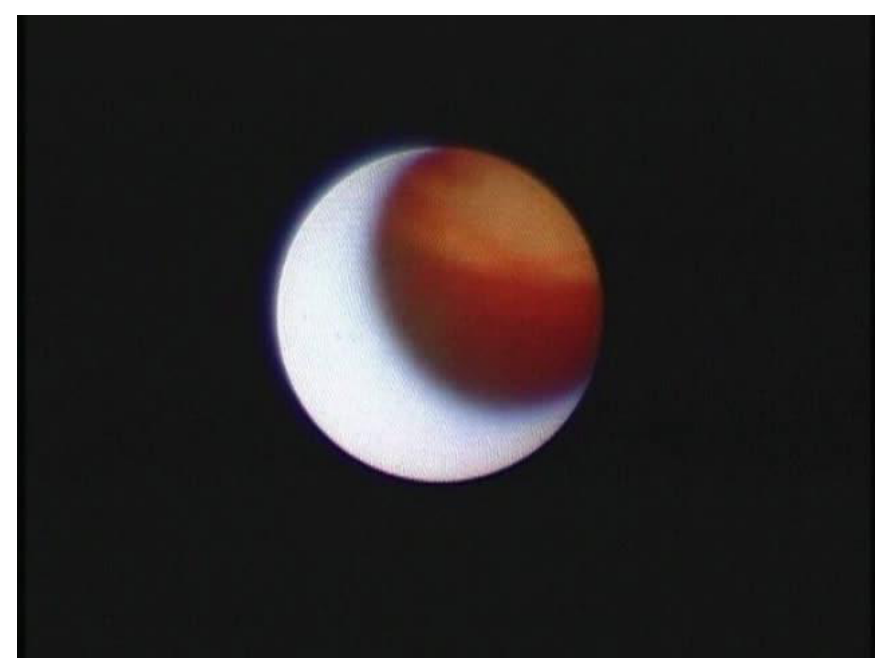

Video 2 Angioscopic video of the mobile white thrombus or flap.

later were $0.79 \mathrm{mg} / \mathrm{dL}$ and $0.43 \mathrm{mg} / \mathrm{dL}$, respectively, with a baseline level of $0.59 \mathrm{mg} / \mathrm{dL}$. These results suggested that no embolic complication occurred after NOA. No embolic complications were observed in 324 consecutive patients within 24 hours after aortic NOA. ${ }^{2}$

The patient's course has been uneventful with conservative management for 2 years. CTA is performed every 6 months, as aortic size was normal. However, there is a limitation to the size-based determination of indications for treatment to prevent unexpected rupture of an aortic aneurysm with dissection, ${ }^{1}$ because asymptomatic aortic plaque ruptures may be associated with aortic fragility. ${ }^{3}$ CTA may overlook such injuries because of limited spatial resolution. ${ }^{3}$ CT and NOA are capable of spatial resolution at $500 \mu \mathrm{m}$ and $150 \mu \mathrm{m}$, respectively. A disadvantage of CTA may be that images are static and tissue characterisation is only based on CT values, and thus may be unable to differentiate non-calcified plaques. The advantage of NOA in the diagnosis of aortic dissection is its ability to detect the entry tear and intimal injury with direct observation and to record these with both images and videos.

\section{Learning points}

Asymptomatic thrombosed type B dissection may be safely diagnosed with non-obstructive angioscopy (NOA).

- NOA is superior to CT angiography because of its higher spatial resolution and its capability of direct recording with both still images and videos.

- The size-based determination of indications for treatment to prevent unexpected rupture of an aortic aneurysm and dissection is a limitation.

NOA may be useful in diagnosing aortic dissection and disrupted intima, including the boundaries of the dissection and entry tear, mobile thrombus and flaps.

Contributors ST wrote the first version of the manuscript. SK and MT supervised the manuscript and gave expert opinion. KK supervised all the processes and gave final approval of this version of the manuscript.

Funding The authors have not declared a specific grant for this research from any funding agency in the public, commercial or not-for-profit sectors.

Competing interests Yes, Dr. Kodama, who is the president of Inter-tec Medicals, Co., Ltd developed non-obstructive angioscopy. Dr, Komatsu is a technical consultant for Nemoto Kyorin-do Co., Ltd., Other authors has no conflict of interest.

\section{Patient consent Obtained.}

Provenance and peer review Not commissioned; externally peer reviewed

Open Access This is an Open Access article distributed in accordance with the terms of the Creative Commons Attribution (CC BY 4.0) license, which permits others to distribute, remix, adapt and build upon this work, for commercial use, provided the original work is properly cited. See: http://creativecommons.org/licenses/by/4.0/

(C) BMJ Publishing Group Ltd (unless otherwise stated in the text of the article) 2018. All rights reserved. No commercial use is permitted unless otherwise expressly granted.

\section{REFERENCES}

1 Komatsu S, Ohara T, Takahashi S, et al. Early detection of vulnerable atherosclerotic plaque for risk reduction of acute aortic rupture and thromboemboli and atheroemboli using non-obstructive angioscopy. Circ J 2015:79:742-50.

2 Komatsu S, Yutani C, Ohara T, et al. Spontaneous ruptured aortic plaques are more frequent and smaller than thought: Novel insights from angioscopy. JACC. In Press,

3 Komatsu S, Ohara T, Takahashi S, et al. Improving the visual field in coronary artery by with non-obstructive angioscopy: dual infusion method. Int J Cardiovasc Imaging 2017;33:789-96.

Copyright 2018 BMJ Publishing Group. All rights reserved. For permission to reuse any of this content visit http://group.bmi.com/group/rights-licensing/permissions.

BMJ Case Report Fellows may re-use this article for personal use and teaching without any further permission.

Become a Fellow of BMJ Case Reports today and you can:

- Submit as many cases as you like

- Enjoy fast sympathetic peer review and rapid publication of accepted articles

- Access all the published articles

- Re-use any of the published material for personal use and teaching without further permission

For information on Institutional Fellowships contact consortiasales@bmjgroup.com

Visit casereports.bmj.com for more articles like this and to become a Fellow 